\author{
ANETA NOTT-BOWER \\ (iD https://orcid.org/0000-0002-4862-1899 \\ Polski Uniwersytet na Obczyźnie w Londynie \\ Londyn
}

\title{
Dwupiśmienność (biliteracy) \\ szansą na zrównoważony rozwój dziecka dwujęzycznego
}

Biliteracy as an opportunity for sustainable development of bilingual children

\begin{abstract}
The author draws attention to the phenomenon of biliteracy, i.e. the ability to read and write in two languages. She presents the ways in which the phenomenon is understood in the context of research on bilingualism and literacy tuition. The high scientific and practical value of the concept is emphasised. A broad and integrated approach to biliteracy is proposed. The acquisition of biliteracy is presented as a multiannual, lifelong process. The author shows the potential of biliteracy in terms of improving bilingual functioning (strengthening the motivation to learn a minority language, supporting linguistic and cognitive development, improving emotional and social comfort of bilingual individuals).
\end{abstract}

Keywords: biliteracy, literacy tuition, bilingualism

\section{Wstęp}

Dwupiśmienność (biliteracy) tradycyjnie definiuje się jako umiejętność czytania i pisania w dwóch językach (Beardsmore 1986; Dufresne 2006), lecz za tym terminem kryje się znacznie więcej treści. Jednym z celów tego artykułu jest wyodrębnienie dwupiśmienności jako interesującego przedmiotu rozważań w nauce o bilingwizmie. Kolejno nakreślę różne sposoby pojmowania tego zjawiska i łączenia go z wynikami dotychczasowych badań na polu dwujęzyczności. Wykażę także, że oprócz wartości naukowej jest to koncept o wysokiej użyteczności praktycznej w edukacji dwujęzycznej. Dwupiśmienność 
może poprawiać funkcjonowanie dwujęzyczne, wzmacniać motywację do nauki języka mniejszościowego ${ }^{1}$, wspomagać rozwój językowy oraz poznawczy osoby dwujęzycznej oraz podnosić komfort emocjonalny i społeczny. Zaproponuję szerokie i zintegrowane ujmowanie tego zjawiska i dostrzeganie w nim szansy dla osób dwujęzycznych na wejście na wyższe poziomy operowania językami - także w mowie. W końcowej części artykułu zwrócę uwagę na fakt, że zdobywanie dwupiśmienności to wieloletni proces, który podobnie jak rozwój językowy - nigdy nie jest zakończony.

\section{Szeroko ujmowana dwupiśmienność a bilingwizm}

Dwupiśmienność to kompetencja, która wykazuje ścisły związek z bilingwizmem. Baker $(2011,3)$ włącza ją do jednego z typów bilingwizmu, charakteryzując dwa rodzaje dwujęzyczności: ze względu na rodzaj opanowanych w obu językach kompetencji. Posługiwanie się obydwoma językami w zakresie wszystkich czterech sprawności językowych (receptywnych: rozumienia ze słuchu, czytania; produktywnych: mówienia, pisania) to dwujezyczność produktywna (inaczej aktywna). Natomiast te osoby dwujęzyczne, które mają dobrze rozwinięte wszystkie sprawności w języku większościowym, a w języku mniejszościowym opanowały tylko sprawności receptywne (rozumienie ze słuchu i/lub czytanie), zalicza do przedstawicieli dwujezyczności receptywnej (dawniej pasywnej) (Baker 2011; Nott-Bower 2017). W ujęciu badacza znaczenie terminu dwujezyczność produktywna obejmuje więc dwupismienność. Jagoda Cieszyńska w artykule o poziomie dwujęzyczności wskazuje podobnie: „Mówiąc o pełnych kompetencjach, mam na myśli umiejętność czytania i pisania w danym języku" (Cieszyńska 2010, 5).

Aby głębiej przeanalizować termin biliteracy, należałoby zwrócić uwagę na jego budowę: bi- plus literacy. Człon bi- w języku angielskim oznacza: podwójny, dwukrotny, dwoisty. Tak samo wyrażona podwójność występuje również w terminie bilingwizm - dwu-języczność (bilingualism). W przypadku biliteracy przedrostek bi-dodano do wcześniej powstałego pojęcia literacy (alfabetyzm, piśmiennośc), co daje sumę znaczeń, które w języku polskim można wyrazić jako: podwójna piśmienność, podwójny alfabetyzm, dwupiśmien-

${ }^{1}$ Język mniejszościowy (ang. minority language) to język nieużywany powszechnie w danej społeczności (Auer, Wei 2009). Język większościowy (ang. majority language) jest językiem, jakim posługuje się większość ludności na danym obszarze (Cummins, Swain 1986). 
ność, bialfabetyzm. Z podanych propozycji najbardziej przemawia do mnie dwupiśmienność, komponuje się bowiem z dwujezycznościq.

Do rozważań nad biliteracy warto przygotować się, zatrzymując się na dłużej przy terminie literacy (alfabetyzm - pismienność), ujmowanym szeroko i posiadającym kilka znaczeń. W literaturze prezentowany jest jako:

- umiejętność czytania, pisania i liczenia, rozumiana również jako umiejętność kognitywna (z zastosowaniem myślenia logicznego, intuicyjnego i kreatywnego) lub zespół procesów kognitywnych;

- umiejętność wykorzystywana w praktyce w różnych kontekstach sytuacyjnych (jak choćby umiejętność adaptująca do funkcjonowania w rodzinie czy środowisku pracy);

- zespół praktyk społecznych i kulturowych zachodzących w specyficznych kontekstach socjoekonomicznych, politycznych, kulturowych i językowych;

- umiejętność jednostki polegająca na rozwoju i wykorzystaniu własnych atutów i kompetencji do realizacji indywidualnych celów;

- instrument krytycznej refleksji i działania na rzecz społecznych procesów przemian (także alfabetyzm krytyczny lub transformatywny) (UNESCO 2013, 21).

Wąska interpretacja piśmienności (w kontekście samej umiejętności czytania i pisania) nie ukazuje w pełni znaczenia tej kompetencji. Literacy rozpatrywana szerzej $\mathrm{w}$ powiązaniu $\mathrm{z}$ aspektami poznawczymi, emocjonalnymi, motywacyjnymi, kulturowo-historycznymi, kreatywnymi i estetycznymi lepiej posłuży celom tego artykułu, bowiem analogicznie do bilingwizmu będzie analizowana w ujęciu podwójnym - jako biliteracy.

W jaki sposób piśmienność w dwóch językach (lub większej ich liczbie) wpływa na funkcjonowanie poznawcze i społeczne osoby bilingwalnej? Logika i doświadczenie nakazują twierdzić, że dwupiśmienność umożliwia kontynuację dwujęzycznego rozwoju oraz usprawnia codzienne funkcjonowanie w dwujęzycznym środowisku. Szerokie i utylitarne ujęcie tego terminu posłuży przyszłym badaniom mogącym potwierdzić tę tezę na gruncie bilingwizmu z językiem polskim. To ujęcie wiąże się ściśle z funkcjonalnym aspektem samej dwujęzyczności, który w moim przekonaniu jest strategiczny w rozpatrywaniu zjawiska bilingwizmu oraz zjawisk pokrewnych, jak np. dwupiśmienności. Marzena Błasiak-Tytuła podkreśla, że „dwu- i wielojęzyczność dzieci może być rozpatrywana jedynie przez pryzmat użycia i oznaczałaby używanie języków w życiu codziennym” (Błasiak-Tytuła 2011, 60). Podobnie rozpatrujmy zatem dwupismiennośc - jako funkcjonalne (czyli 
zaspokajające wszystkie potrzeby) używanie dwóch lub większej liczby języków w formie pisma ręcznego i druku. Do rozważań nad dwupiśmiennościa analogicznie do rozważań nad nauką czytania należy wykroczyć poza samą technikę transformacji znaków graficznych w znaki dźwiękowe i odwrotnie (podejście lingwistyczne). Szerokiemu ujęciu dwupiśmienności odpowiada psychologiczne podejście do czytania, nazywane też psycholingwistycznym lub pedagogiczno-psychologicznym, gdzie nacisk kładzie się na rozumienie odczytywanego tekstu. Akcentuje się „złożoność, wieloaspektowość i znacznie szerszy zakres operacji językowych i poznawczych składających się na kompetencje związane z czytaniem” (Klus-Stańska, Nowicka 2009, 17).

\section{Dwupiśmienność jako sprawność zintegrowana}

Tradycyjnie dwujęzyczność opisywano jako biegłość językową w dwóch osobnych językach, czyli opierano się na idei oddzielnych systemów językowych (L1 i L2) o różnych cechach. Ten pogląd rozszerzył się również na rozwój umiejętności czytania i pisania w dwóch systemach językowych. Z tej perspektywy doskonalenie kompetencji czytania i pisania w jednym języku odzwierciedla tę sprawność w drugim języku, a tym samym potwierdza teorię istnienia dwóch równoległych jednojęzycznych osób w jednym ciele (Grosjean 1989). Francois Grosjean (1989) w wielokrotnie cytowanym artykule Neurolinguists, Beware! The Bilingual Is Not Two Monolinguals in One Person skrytykował ograniczony pogląd na bilingwizm, przeciwstawiał „ułamkowemu”, jednojęzycznemu postrzeganiu wielojęzyczności to, co nazywał poglądem „całościowym”. Inni badacze także wykazali, że osoby bilingwalne używają swoich języków w sposób sugerujący zintegrowany system językowy (Wolfersberger 2003). Umocniło się tym samym postrzeganie ich jako aktywnych komunikujących się, którzy korzystają z cech językowych obu swoich języków (Bauer 2017, 2-3).

Analogicznie proponuję nie definiować dwupiśmienności jako umiejętności czytania i pisania w sensie czynności, która odbywa się ściśle w ramach każdego języka osoby bilingwalnej. Dwupiśmienność oznacza aktywność kompleksowa - to, jak człowiek dwujęzyczny potrafi korzystać ze słowa pisanego w swoich językach ze świadomością, że oba kody są zawsze obecne i aktywne, nawet podczas używania tylko jednego z nich (Bauer 2017, 2-3). Ten pogląd jest zgodny z wprowadzona w 1979 roku teorią Common Underlying 
Proficiency Cumminsa, wyjaśniająca, w jaki sposób współzależność poznawcza pozwala na transfer umiejętności językowych, mimo że elementy strukturalne obu języków moga wyglądać inaczej. Cummins włącza dwupiśmienność do swojej tezy funkcjonowania dwujęzycznego i postuluje, że umiejętności czytania i pisania u osób bilingwalnych nie są związane z konkretnym językiem. Bez względu na to, który kod używany jest w danym momencie, myśli towarzyszące mówieniu, czytaniu, pisaniu i słuchaniu pochodzą z tego samego centralnego systemu. To, czy jednostka posługuje się jednym, dwoma lub więcej językami, ma jedno zintegrowane źródło myśli (Cummins 1979).

\section{Dwupiśmienność a poziom kompetencji w zakresie mówienia w dwóch językach}

W kontekście badań nad dwupiśmiennością istotna jest typologia bilingwizmu ze względu na poziom kompetencji w obu językach. Bilingwizm pełny (symetryczny) to jednakowo wysokie i odpowiednie do wieku opanowanie obu kodów (podobne do stopnia posługiwania się językiem ojczystym). Żaden z języków nie przejawia dominacji, czyli występuje między nimi symetria. Jest on mierzony według monolingwalnych norm, tzn. w obu systemach, we wszystkich obszarach aktywności, osoba w pełni bilingwalna nie powinna przejawiać żadnych śladów interferencji: cech fonologicznych, morfologicznych czy syntaktycznych, charakterystycznych tylko dla L1, a obecnych w jego produkcjach w L22. Bilingwizm średniego s to p nia (asymetryczny) to odpowiedni do wieku poziom posługiwania się językiem dominującym (L1). Drugi kod (L2) nie jest wystarczająco rozwinięty i można zaobserwować w nim wyraźne różnice w porównaniu z językiem monogloty. Osoba reprezentująca bilingwizm niskiego stopnia (semilingwizm, półjęzyczność) przejawia ilościowe i jakościowe deficyty w obu językach w porównaniu z osobą jednojęzyczną (Baker 2011; Nott-Bower 2017; Skutnabb-Kangas 2007, 136).

Rozważmy problem związku pomiędzy poziomem kompetencji bilingwalnej a dwupiśmiennością. W moim przekonaniu jest to zależność wprost proporcjonalna oraz dwukierunkowa. U większości dzieci bilingwalnych, z którymi pracuję, język większościowy w mowie i w piśmie jest

2 O ograniczeniach tego terminu napiszę w dalszej części artykułu. 
rozwinięty zgodnie z normą wiekowa, a język polski - jako ten mniejszościowy - jest na stosunkowo niskim poziomie (bilingwizm średniego stopnia). Dzieci te niekiedy doskonale opanowuja techniczny aspekt czytania po polsku: perfekcyjnie rozkodowują tekst pisany, przekładają go na dźwięki języka polskiego z zachowaniem zasad specyficznych dla tego systemu. Ale zapytane o treść, tego co właśnie głośno przeczytały, nie potrafią udzielić pełnej lub poprawnej odpowiedzi. W kontekście tego artykułu nasuwa się pytanie: czy można je określić jako dwupiśmienne (biliterate)? Uważam, że nie. Powołam się na definicję pierwotnie stworzona przez Milesa A. Tinkera w 1952 r. i zrewidowaną wspólnie z Constance M. McCullough w 1962 r., według której

czytanie polega na rozpoznawaniu symboli (drukowanych lub pisanych), stanowiących bodziec do aktualizowania znaczeń wbudowanych w doświadczenie jednostki oraz do powstawania nowych znaczeń znanych już słów poprzez manipulowanie pojęciami już posiadanymi (Tinker, McCullough 1962, 13).

W opisywanym przykładzie dziecko rozpoznaje symbole graficzne w tekście, ale przez obniżoną kompetencję w języku polskim nie uruchamia znaczeń ani nie tworzy nowych. Zatem nie rozumie, co czyta, więc nie czyta, tylko odczytuje. Nie uważam jednak, że opisana powyżej grupa nie powinna korzystać z tej ograniczonej kompetencji. Czytanie prostych tekstów wspartych obrazkami oraz uzupełnionych wyjaśnieniem dorosłego może stać się skutecznym ćwiczeniem rozwijającym zarówno bilingwizm, jak i dwupiśmienność.

Podobne obserwacje czyni Jagoda Cieszyńska, w czasie wywiadów z młodzieżą dwujęzyczną:

Młodzież, z którą rozmawiałam podczas pobytu w Lyonie i w Wiedniu zwracała uwagę na swoje trudności w rozumieniu tekstów pisanych. Uczniowie byli zdziwieni, że tak dobrze sobie radzą podczas codziennej komunikacji w języku polskim, a napotykają trudności podczas czytania (Cieszyńska 2010, 13).

Autorka zwraca uwage, że tylko kontakt ze słowem pisanym pozwala na poszerzenie słownictwa, rozbudowanie struktur gramatycznych, czyli wzrost kompetencji językowej i wyjście poza język małego użytkownika danego systemu. Dodatkowo, jak wskazują Rabiej i Dębski, ćwiczenia rozwijające dwu- 
piśmienność moga mieć pozytywny wpływ na wymowę dziecka dwujęzycznego:

Nauka czytania stwarza okazje rodzicom i opiekunom, by ukierunkowywać uwagę dziecka na prawidłową wymowę poszczególnych głosek, korygować wymowę błędna, a w przypadku dzieci dwu- lub wielojęzycznych dodatkowo ćwiczyć dźwięki, które są dla nich trudne ze względu na transfer pomiędzy językami (Rabiej, Dębski 2017, 59).

Jak wykazałam już wcześniej, dwupiśmienność może stać się użytecznym celem, do którego dążenie będzie wspierać rozwój dwujęzyczności - także w zakresie samego mówienia.

W przypadku dzieci reprezentujących bilingwizm niskiego stopnia należałoby przypuszczać, że trudności w czytaniu ze zrozumieniem będą się przejawiać w obu językach i również nie będziemy mieć do czynienia z dwupiśmiennością. Znów praca z tekstem z odpowiednim wsparciem może być tu zastosowana jako forma terapii. Rabiej i Dębski słusznie zauważają, że

czytanie postrzegane jest jako rodzaj profilaktyki i/lub terapii dzieci z opóźnionym rozwojem mowy, wadami wymowy lub innymi specjalnymi potrzebami edukacyjnymi. Pismo wykorzystuje się wówczas w pracy z dziećmi w wieku przedszkolnym lub młodszym, by zapobiegać potencjalnym dysfunkcjom, wspierać prawidłowy rozwój poznawczy i językowy dzieci (Rabiej, Dębski 2017, 54).

W tym ujęciu bilingwizm niskiego stopnia będzie można zaliczyć do specjalnych potrzeb edukacyjnych.

Wielu badaczy uważa bilingwizm pełny (symetryczny) za konstrukt teoretyczny w rzeczywistości nieistniejący: „Pojęcie dwujęzyczności symetrycznej jest pojęciem idealnym, które jest w dużej mierze artefaktem perspektywy teoretycznej, która przyjmuje jednojęzyczność jako punkt odniesienia" (Romaine 1989, 18 za: Treffers-Daller 2015, 23). Jako praktyk jestem świadoma ograniczeń, które niesie termin bilingwizm symetryczny. Nasuwa użytkownikowi nierealistyczne skojarzenie $z$ obrazem dwóch osób jednojęzycznych w jednym ciele. Z tą świadomością chciałabym się (w ramach rozważań teoretycznych) odnieść do zjawiska dwupiśmienności w grupie osób dwujęzycznych. Na potrzeby tego artykułu pojmuję go jako bilingwizm z kompetencją w L1 i L2 rozwiniętą na poziomie umożliwiającym skuteczną komunikacje za pomocą mowy głośnej oraz na czytanie ze zrozumieniem tekstów ade- 
kwatnych do wieku. W przypadku dzieci reprezentujących ten typ bilingwizmu można już mówić o dwupiśmienności, ale nadal dostrzegam tu zastosowanie pracy z tekstem jako formy dalszego doskonalenia kompetencji dwujęzycznej. Mam na myśli ćwiczenia wspierające naukę czytania na wyższych poziomach, kiedy angażowane są czynności związane z rozumieniem i stosowaniem ironii, metafory, zmiennych punktów widzenia, wchodzenia pod powierzchnię tekstu. W dalszej części rozważań powrócę do długofalowego ujmowania dwupiśmienności.

W kontekście bilingwizmu często poruszana jest kwestia prestiżu języka. Kiedy dany kod mniejszości ma niski prestiż społeczny, obniża się motywacja do używania go i dalszego doskonalenia. Dwupiśmienność może stać się użytecznym narzędziem podnoszenia rangi dwujęzyczności bez względu na zaangażowane języki. W Stanach Zjednoczonych przyznawana jest nagroda Seal of Biliteracy ${ }^{3}$, jest to wyróżnienie za biegła znajomość języka angielskiego oraz języka drugiego (bez względu na sposób lub miejsce nauki L2) dla uczniów kończących szkołę średnią. Posiadanie certyfikatu Seal of Biliteracy świadczy o biegłości absolwenta w przynajmniej dwóch językach. Obejmuje ona cztery kategorie: mówienie, czytanie, słuchanie i pisanie. Dyplom pozwala potencjalnym pracodawcom na identyfikację osób w pełni kompetentnych w dwóch językach, a absolwentom umożliwia zdobycie dodatkowych punktów w procesie kwalifikacji na uczelnie wyższe. The Seal of Biliteray promuje bilingwizm i oferuje młodzieży wymierna zachętę do pracy nad doskonaleniem dwujęzyczności i dwupiśmienności.

\section{Dwupiśmienność a kompetencja poznawcza CALP}

Praca nad rozwojem dwupiśmienności u dzieci dwujęzycznych może posłużyć jako element rozwijania komunikacji wymagającej poznawczo, podnosi funkcjonowanie dwujęzyczne. Zróżnicowanie pomiędzy elementarnymi umiejętnościami komunikacyjnymi - BICS (basic interpersonal communication skills) a poznawczą akademicką sprawnością językowa - CALP (cognitive academic language proficiency) w 1979 roku wprowadził Jim Cummins (1979). Kompetencja BICS (zwana przez innych autorów kompetencją konwersacyjna, biegłościa powierzchowna) jest wymagana na podstawowym pozio-

${ }^{3}$ https://sealofbiliteracy.org/ [dostęp: 20.08.2020]. 
mie kontaktów międzyludzkich. Kompetencja CALP (określana też jako akademicka) jest potrzebna w sytuacjach wymagających poznawczo, kiedy kontekst jest ograniczony, a zrozumienie komunikatu bazuje jedynie na jego zawartości słownej. Sprawność językowa CALP jest narzędziem poznawczym, koniecznym do zwerbalizowanego rozumowania, czytania i innych operacji, które wymuszają użycia danego kodu (Baker 2011, 139-141; Nott-Bower 2014, 62-63). Wprowadzenie edukacji w zakresie dwupiśmienności u dzieci dwujęzycznych może pomóc im w rozwinięciu biegłości CALP w obu językach, a tym samym posłużyć do pełnego wykorzystania potencjału bilingwizmu. Podobnie uważa Agnieszka Rabiej (2017, 271): „tekst jest najlepszym narzędziem wspierającym rozwój kompetencji tzw. akademickich (CALP) u uczniów". Bernadetta Niesporek-Szamburska przywołuje badania Cumminsa (1984) - twórcy teorii podwójnej góry lodowej, która zakłada, że dwa języki osoby dwujęzycznej opierają się na wspólnych procesach poznawczych:

Oznacza to, że umiejętności językowe mogą być łatwo przetransferowane z jednego języka do drugiego. Im silniejszy funkcjonalnie pierwszy język (większościowy) - szczególnie gdy użytkownik operuje nim już na poziomie poznawczym i edukacyjnym/teoretycznym (CALP) - tym lepiej rozwija się u niego drugi język (Niesporek-Szamburska 2018, 104).

Autorka sugeruje uwzględnienie odkryć Cumminsa w pracy z tekstami (przez dostosowywanie wsparcia kontekstowego) w celu podniesienia kompetencji akademickiej CALP w języku mniejszości, co także zaowocuje wzrostem poznawczym użytkownika języka.

\section{Dwupiśmienność jako wieloletni proces alfabetyzacji}

Dzięki nauce czytania i pisania język mniejszościowy może wykroczyć poza granice rozmów codziennych, domowych, konkretnych. Dodatkowo za promowaniem dwupiśmienności wśród dzieci dwujęzycznych przemawiają obserwacje, że umiejętność czytania i pisania w języku mniejszościowym wspiera proces alfabetyzacji ${ }^{4} \mathrm{w}$ języku większościowym (Collier, Thomas 1995, Krashen, Biber 1987). Początkowe etapy alfabetyzacji (emer-

4 Alfabetyzację definiuje się jako „fundamentalny proces edukacji, w wyniku którego człowiek rozwija umiejętność pisania i czytania, zgodnie z alfabetem przyjętym w danym kraju, oraz umiejętność liczenia” (Przybylska 2011, 29). 
gent literacy) są bezsprzecznie istotne w edukacji wszystkich dzieci (Rabiej, Dębski 2017). W przypadku tych bilingwalnych wczesna nauka czytania w języku mniejszościowym (w rozumieniu nauki przed rozpoczęciem formalnej edukacji w języku większościowym) może posłużyć rozwojowi danego systemu oraz kompetencji czytelniczych. Poznanie samej techniki czytania jest niewattpliwie konieczną podstawą dwupiśmienności. Jeżeli dziecko dwujęzyczne osiagnie tu biegłość w języku mniejszościowym, znajdzie większą motywację do sięgania po lektury w tym języku, a dzięki temu będzie dalej rozwijać swoją dwupiśmienność w zakresie rozumienia i przetwarzania tekstu.

W literaturze światowej można znaleźć wiele opracowań dotyczących nauki czytania przez dzieci. Wiele z nich uważa się za uniwersalne: „Kierunek rozwoju zdolności fonologicznych ma charakter uniwersalny w ramach różnych języków europejskich, a przebieg procesu przyswajania dekodowania jest podobny" (Krasuska-Betiuk 2018, 74). Przykładem może być popularna uniwersalna trójfazowa koncepcja rozwoju umiejętności czytania dzieci w wieku od sześciu do dziewięciu lat autorstwa Uty Frith (1985). Przestrzega się jednak przed bezkrytycznym stosowaniem modelów stworzonych na podstawie języka angielskiego w innych krajach bez rozważenia różnic wypływających ze specyfiki systemu, używanych metod nauczania czy wieku, w którym dzieci rozpoczynają szkolną naukę czytania (Sochacka 2004, 108). Opracowano też koncepcje specyficzne dla języka polskiego, np. model G. Krasowicz-Kupis (2008) obejmujący naukę czytania od klasy zerowej do klasy trzeciej. Zwracam uwagę, że wiele publikacji koncentruje się na początkowych etapach alfabetyzacji: dwa przytoczone wcześniej przykładowe modele dotyczą dzieci w wieku wczesnoszkolnym. W kontekście badań nad dwupiśmiennością chciałabym zwrócić uwagę na znaczenie dalszych etapów przyswajania umiejętności czytania. Przywołam koncepcję M. Wolf (2008), która naukę tę postrzega jako wieloletni proces i proponuje pięć etapów jej rozwoju:

- wschodzący „przedczytelnik” (the emerging pre-reader) - zazwyczaj w wieku od 6 miesięcy do 6 lat;

- czytelnik początkujący (the novice reader) - najczęściej w wieku od 6 do 7 lat;

- czytelnik dekodujacy (the decoding reader) - zwykle w wieku 7-9 lat;

- biegły, rozumiejący czytelnik (the fluent, comprehending reader) - zazwyczaj w wieku od 9 do 15 lat;

- czytelnik ekspert (the expert reader) - zwykle od 16. roku życia. 
Kiedy dzieci po raz pierwszy uczą się operować literami i dźwiękami, wchodzą w pierwszy etap i stają się wschodzacymi „przedczytelnikami”. W miarę jak uczniowie coraz lepiej posługują się literami i uczą się odkodowywać łatwe słowa i zdania, rozpoczynaja etap caytelnika poczatteujacego. Zaczynaja rozwijać podstawowe rozumienie zasad fonologicznych, ortograficznych i semantycznych języka. Caytelnik dekodujacy potrafi płynnie czytać słowa i zdania. Zamiast zużywać większość energii na odszyfrowywanie słów, jego mózg ma szansę aktywować obszary związane ze znaczeniem, rozumieniem i pamięcią. Kiedy czytanie staje się w pełni zautomatyzowane i coraz częściej angażuje myślenie na wyższym poziomie, dziecko wchodzi na poziom biegtego, rozumiejacego czytelnika. Uczeń czyta teraz tak sprawnie, że jego mózg ma wystarczająco dużo czasu, aby zrozumieć, wywnioskować, a nawet przewidzieć treść. Dzięki tekstom doskonali i rozwija umiejętność doświadczania świata, by ostatecznie osiagnać piąty stopień - staje się profesjonalistą w czytaniu (caytelnik - ekspert). Jednak ostatni etap nie ma kształtu plateau. Umiejętność czytania nigdy nie przestaje się rozwijać. Wraz z poprawą płynności i poszerzeniem wiedzy o świecie dzieci odblokowują coraz więcej funkcji tekstu, z którym pracują. W ten sposób młodzi czytelnicy uczą się pojmować ironię, metafory i zmienne punkty widzenia oraz zaczynają łączyć to, co czytaja z własnymi doświadczeniami i otaczającym ich światem. Bardzo interesująca byłaby weryfikacja modelu Wolf (2008) na polskim gruncie oraz w kontekście bilingwizmu.

Nauka czytania jest to bieg długodystansowy, a wręcz niekończący się proces. Podobnie powinna być postrzegana piśmienność obejmująca dwa lub większą liczbę języków. Z tą samą troską podchodźmy do dwupiśmienności zarówno na poczattkowych etapach nauki, jak i w tych dalszych. Zakładam, że regularna edukacja w języku większościowym zadba o doskonalenie czytania na początkowym oraz wyższym poziomie. Do pełni sukcesu wystarczy postępować tak samo w zakresie języka mniejszościowego, wykorzystując wspólny fundament poznawczy obu języków.

\section{Podsumowanie}

Dwupiśmienność to wartościowy koncept w edukacji dwujęzycznej oraz w badaniach nad bilingwizmem. Pojmowana szeroko oraz postrzegana jako kompetencja ściśle związana z dwujęzycznością lub wręcz będąca jej skład- 
nikiem jest wartością sama w sobie, a praca nad nią może być użytecznym narzędziem w rozwijaniu i pogłębianiu kompetencji bilingwalnej. Podkreślam, aby na wzór bilingwizmu dwupiśmienność traktować jako kompetencję zintegrowana, a nie jako równoległe procesy w dwóch niezależnych systemach językowych. Praca z tekstem jako element rozwijania dwupiśmienności u dzieci dwujęzycznych ma zastosowanie na każdym poziomie biegłości bilingwalnej uczniów, przenosi ich bowiem na wyższe szczeble akademickiej kompetencji językowej (CALP). Dodatkowo umożliwia zdobywanie wiedzy w dwóch językach, co może równocześnie stymulować rozwój poznawczy (Nott-Bower 2014). Są też plusy w innych ważnych sferach funkcjonowania osoby bilingwalnej: „Dostępność pisma w obu językach ma znaczenie dla pozytywnego przeżycia własnej dwujęzyczności przez dziecko, ograniczając również siłę oddziaływania procesu submersji językowej w przypadku naturalnej konkurencji między językami w warunkach imigracyjnych" (Rabiej, Dębski 2017, 217). Zwracam jednak uwagę na to, aby dwupiśmienność rozwijać w procesie długofalowym, nie koncentrować się tylko na początkowym, czysto technicznym aspekcie nauki czytania i pisania. Koncept ten stanowi interesujący temat dalszych badań naukowych.

\section{Bibliografia}

Auer P., Wei L., 2009, Handbook of Multilingualism and Multilingual Communication, Berlin.

Baker C., 2011, Foundations of Bilingual Education and Bilingualism, Bristol.

Bauer E.U., 2017, Biliteracy, Illinois.

Beardsmore H.B., 1986, Bilingualism: basic principles (Vol. 1), Clevedon.

Błasiak-Tytuła M., 2011, Kilka unvag na temat bilingwizmu, w: Michalik M., red., „Nowa Logopedia", t. 2: Biologiczne unvarunkowania rožwoju $i$ zaburzen mony, Kraków.

Cieszyńska J., 2010, Dwujezycznosíc - rozumienie siebie jako Innego, w: Cieszyńska J., Orłowska-Popek Z., Korendo M., red., Nowe podejscie w diagnozie i terapii logopedycznej - metoda krakowska, Kraków.

Collier V., Thomas W., 1995, Language Minority Student, Acbievement and Program Effectiveness, Washington.

Cummins J., 1979, Cognitive/academic language proficiency, linguistic interdependence, the optimum age question and some other matters, "Working Papers on Bilingualism", nr 19.

Cummins J., 1984, Bilingual Education and Special Education, Issues in Assessment and Pedagogy, San Diego.

Cummins J., Swain M., 1986, Bilingualism in Education, Nowy Jork.

Dufresne T., 2006, Literacy and school practices: What can we learn from how children conceptualize language in multiliterate environments?, Oxford.

Frith U., 1985, Beneath the surface of developmental dyslexia, w: Patterson K., Coltheart M., Marshall J., red., Surface Dyslexia, Londyn. 
Grosjean F., 1989, Neurolinguists, Beware! The Bilingual Is Not Two Monolinguals in One Person, „Brain And Language”, nr 36.

Klus-Stańska D., Nowicka M., 2009, Sensy i bezsensy edukacji wožesnoszkolnej, Warszawa.

Krashen S., Biber D., 1987, On Course: Bilingual Education's Success in California, Sacramento.

Krasowicz-Kupis G., 2008, Psychologia dysleksji, Warszawa.

Krasuska-Betiuk M., 2018, Szkolna nauka czytania i pisania z. wykoryystaniem wybranych elementarzy - refleksje metodyczne, „Forum Pedagogiczne”, nr 2018/2.

Niesporek-Szamburska B., 2018, Kompetencja tekstotwórcza w jezylku odziedziczonym, czyli o kreacji $i$ zabawie w procesie tworzenia tekstów, „Postscriptum Polonistyczne”, nr 2 (22).

Nott-Bower A., 2014, Dwujezyczność a rozwój poznawczy. Szanse i zagrożenia, w: Kuros-Kowalska K., Loewe I., red., Dwnjezyczność, wielojezyczność i wielokulturowość. Szanse i zagrożenia na drodze do porozumienia, Gliwice.

Nott-Bower A., 2017, Skutecznie przekazać jezyk polski. Charakterystyka polonijnych rodzin dwujezycznych, w: Kuros-Kowalska K., Loewe I., Moćko N., red., Dwujezyczność, wielojezyczność i wielokulturowość. Edukacja i globalizacja, Gliwice.

Przybylska E., 2011, Alfabetyzacja i edukacja podstawowa osób dorostych jako wyzwanie teraźniejszości, Toruń.

Rabiej A., 2017, Cyytanie jako umiejętnosic kluczowa w nauce jezyke poprzę treść u dzieci dwujezycznych, w: Zarzycka G., Karasek M., red., „Acta Universitatis Lodziensis. Kształcenie Polonistyczne Cudzoziemców”, nr 24.

Rabiej A., Dębski R., 2017, Czytanie jako sposób na rozwijanie i wychowanie dzieci (nie tylko) dwujezycznych, „Języki Obce w Szkole”, nr 4/2017.

Skutnabb-Kangas T., 2007, Bilingualism or Not-The Education of Minorities, Clevedon.

Sochacka K., 2004, Rozwój umiejętności czytania, Białystok.

Tinker M.A., McCullough C.M., 1962, Teaching Elementary Reading, Nowy Jork.

Treffers-Daller J., 2015, Do balanced bilinguals exist? A critical review of language dominance, Thessaloniki.

UNESCO Institute for Lifelong Learning, 2013, The second Global Report on Adult Learning and Education, Hamburg.

Wolf M., 2008, Proust and the squid: the story and science of the reading brain, Cambridge.

Wolfersberger M., 2003, L1 \& L2 writing process and strategy transfer: A look at lower proficiency writers, TESL-EJ, 7(2), http://www.tesl-ej.org/wordpress/issues/volume7/ej26/ej26a6/ [dostęp: 20.08.2020].

\section{Netografia}

https://sealofbiliteracy.org/ [dostęp: 20.08.2020].

Aneta Nott-Bower - dr, Zakład Dydaktyki Polonijnej, Polski Uniwersytet na Obczyźnie w Londynie, Londyn, Wielka Brytania.

Wspiera rozwój języka polskiego u dzieci dwujęzycznych, organizuje szkolenia oraz tworzy serwis internetowy dla rodziców, nauczycieli i logopedów. Zainteresowania naukowe: 
bilingwizm, dwukulturowość. Najważniejsze publikacje: Diagnoza oraz terapia zaburzeń mowy i języka u osób dwujęzycznych (Katowice 2015); Skutecznie przekazać język polski. Charakterystyka polonijnych rodzin dwujęzycznych (Gliwice 2017); Bezobrazkowe badanie poziomu rozwoju kompetencji narracyjnej u dzieci jedno- $i$ dwujęzycznych (Katowice 2018).

Kontakt: nott-bower@live.co.uk 